\title{
Entry Mode Strategy, Firm-Level Capability, Environmental Turbulence, and Organisational Performance: A Moderated Analysis
}

\author{
Abiodun B. ONAMUSI ${ }^{1}$ \\ Grace O. MAKINDE 2 \\ Babatunde H. AKINLABI ${ }^{3}$
}

\begin{abstract}
This study examined the effect of entry mode strategy and firm-level capability on organisational performance of selected Fast-Moving Consumer Goods (FMCG) manufacturer in Lagos State, Nigeria; more so, it investigated the moderating effect of environmental turbulence on the interaction between entry mode strategy and firm-level capability, and organisational performance. The cross-sectional survey research design was adopted with a sample of 452 employees of twelve selected FMCGs manufacturers in Lagos State, Nigeria. A hierarchical regression analysis was conducted to substantiate the moderation-effect hypotheses formulated. Findings showed that entry mode strategy and firmlevel capability have a positive and significant effect on organisational performance. Further analysis showed that the interaction term of environmental turbulence, firm-level capability, and entry mode strategy explained the increase in organisational performance with the introduction of environmental turbulence as a moderator. Beyond the performance-effect of entry mode strategy and firm-level capability, management needs to keep abreast of issues happening in the external environment and proactively position their organisation to take advantage of the environment's opportunities while reducing exposure to negative consequences.
\end{abstract}

KEYWORDS: dynamic capability theory, eclectic theory, entry-mode strategy, firm-level capability, organisational performance

JEL CLASSIFICATION: F23, L25, L66, M16

\section{INTRODUCTION}

The desire to achieve year-on-year business performance is an objective many organisations seek to achieve, including FMCG manufacturers in Lagos State, Nigeria. However, achieving continuous incremental performance is not an easy task for many organisations considering the uncertainties in a fast-changing environment. Although the manufacturers in the FMCG (baby-care) industry in Nigeria recorded a marginal 1\% improved performance in 2017 when compared with 2016 , with a retail volume growth rate of $6 \%, 7 \%$, and $7 \%$ on all products categories; milk, cereal, and body-care (Euromonitor International, 2018) respectively. Nevertheless, per capita consumption of baby-care products remains low compared with countries in the same region and despite the rising birth rate of $36.9 \%$ in 2017 to $38.09 \%$ in 2018 (National Population Commission, 2018). Likewise, the enormous costs associated with sourcing raw materials, product development, marketing, innovation, and stringent

\footnotetext{
${ }^{1}$ Department of Management \& Accounting, Lead City University, Ibadan Oyo State, Nigeria abiodunonamusi@gmail.com, corresponding author

${ }^{2}$ Department of Business Administration \& Marketing, Babcock University, Ilishan-Remo Ogun State, Nigeria

${ }^{3}$ Department of Business Administration \& Marketing, Babcock University, Ilishan-Remo Ogun State, Nigeria
} 
legislations are restraining the organisational performance of manufacturers of baby-care products from moving ahead (Westat Nigeria report, 2018).

To corroborate Westat Nigeria's 2018 report, Euromonitor International report on baby and child-specific products in Nigeria (2019) stressed that the penetration of baby and childspecific products in Nigeria is relatively low; the category is still quite far from reaching its full market potential. Perhaps the inability to adopt an appropriate market entry strategy may have led to the low marketing penetration observed by Euromonitor (2019) and consequently impacting the industry performance negatively. Besides the operational entry-mode strategy issue for local manufacturers, marketing challenges have further hampered the growth of the market performance of these organisations because the industry is heavily restricted from taking advantage of several marketing mediums to get to their customers (Euromonitor International, 2017; Westat Nigeria report, 2018). In addition, challenges in this industry are compounded for local manufacturers who possess weak innovative capability (Lekhanya et $a l ., 2017)$ when compared with foreign-owned manufacturers to develop new products that are without complaints and to manage the many challenges including infrastructure inadequacies and legislative restrictions present in Nigeria business environment (Ukpabio et al., 2017). These problems have hampered the development of this sector and have, in most cases, led to the winding up of several manufacturing firms in Nigeria (Lekhanya et al., 2017; Sylva et al., 2016).

In the face of these country-specific challenges, scholars have emphasised that to guarantee prosperity for an organisation operating within a turbulent environment, such organisation must possess distinct resources and core competencies; a dynamic capability; one that can adapt to changing external environment (Zhang \& Hartley, 2018). Such capabilities include the ability to decide on a suitable entry strategy into an international market, innovate both management and technological processes, engage customers in a co-creation responsibility, develop new products, and abilities to conduct active market sensing, planning, and implementation. While this above narrative seems conceptually logical, it is essential to conduct an empirical study to substantiate whether entry-mode strategy appropriateness and deploying critical firm-level capabilities would explain significant variation in FMCG manufacturers' organisational performances in Lagos State, Nigeria.

Subsequent to these discussions, the objective of this study is to evaluate the joint effect of entry-mode strategy and firm-specific capability on organisational performance and to investigate the moderating effect on environmental turbulence on the interaction between entry mode strategy, firm-level capability, and organisational performance of selected FMCG manufacturers in Lagos State, Nigeria.

\section{LITERATURE REVIEW}

\subsection{Theoretical framework and hypotheses development}

Academic writing in management research has employed the use of theories to provide theoretical justification for their studies. This study follows similar practise and draw on two theories (eclectic theory and dynamic capability theory) to substantiate the interaction of the variables under investigation. The eclectic perspective is of specific importance to this study because it explains the dependent (firm performance) interactions and independent (entry strategy and firm-level capability) variables identified in the present study. 
Lending support for the eclectic theory, Brouthers and Hennart (2007) pointed out that eclectic theory is a primary theoretical justification applied in foreign market entry choice literature. The eclectic theory's assumptions are the mechanisms of the eclectic paradigm analysis: Ownership, Location, and Internalization advantages. According to Dunning (2000), the first assumption, ownership, suggests the possession of specific firm-level capabilities that firms can deploy to gain competitive advantage. Second, the location suggests that firms need to operate in an environment that offers location-cost economies like cheap labour, access to resources in the market, and infrastructure that can aid cost-effective production and offers an opportunity for growth. Comparative cost analysis and Porter's industry analysis help firms establish a suitable location where the firm can achieve location advantage. Lastly, internalization suggests the possibility of transferring a firm ownership-advantage to a foreign market within its organisation rather than engaging in other contractual arrangements to do so. According to Dunning, these fundamentals explain how a firm can access foreign markets successfully.

Second, the dynamic capability theory suggests firms that can integrate, develop unique internal and external competencies and constantly reconfigure these competencies stands a better chance of achieving competitive advantage in a changing environment (Lee et al., 2016; Teece, 2014a). This suggests that there must be a direct and indirect interaction between the ownership of dynamic internal-external capabilities and superior firm performance (Chukwuemeka \& Onuoha, 2018; Kaur \& Mehta, 2017; Zhang \& Hartley, 2018). More so, firm-level capability such as customer engagement, new product development, marketing capability, and innovation capability are considered dynamic capabilities that explain how firms achieve attractive new product performance. Overall, given the main deduction of the eclectic theory and dynamic capability theory, this study proposed that: (H1) entry mode strategy and firm-level capability will explain significant variation in organisational performance. More so, $(\mathrm{H} 2)$ the introduction of environmental turbulence would significantly moderate the effect entry mode strategy and firm-level capability has on organisational performance.

\subsection{Empirical Review}

\subsubsection{Entry-mode Strategy, Firm-Specific Capability, and Organisational Performance}

Arasa and Gideon (2015) examined the effect of international market entry strategies on the organisational performance of manufacturing MNE in Kenya. The study revealed that entrymode strategies (licensing $\&$ direct investment) positively affect organisational performance. While other entry-modes showed otherwise. Within the context of Norway, Nisar, Boateng, and $\mathrm{Wu}$ (2018) posited that the entry mode strategy's performance-effect is positive and significant. Further analysis showed that the equity entry-mode strategy had a significant impact on firm performance. Arasa and Gideon (2015) and Nisar et al. (2018), provided support for the finding of Siripaisalpipat and Hoshino (2000), which posited that an appropriate entry mode is critical for organisational performance within MNEs in Thailand.

Quite the reverse, Hollender, Zapkau, and Schwens (2017) assessed the interaction between entry mode strategy choice, international experience, product adaptation, and foreign venture performance. This study revealed that SMEs' foreign market entry-mode (non-equity) choice has no direct effect on foreign venture performance. However, pairing non-equity entrymodes with international experience and product adaptation enables resource-constrained organisations to compensate for the performance disadvantages of non-equity modes compared to the more resource-intense equity entry-modes. 
Regarding the interactions of firm-level capability and organisational performance, Contractor, Yang, and Gaur (2016) examined the performance effect of firm-specific capability and found that firm-specific capability (intangible assets) contributes positively to organisational performance. Kimura and Pugel (1995) stressed that ownership of firm-specific resources such as proprietary products, product or process technologies, specialised knowhow about production, and management or marketing capabilities leads to competitive advantage.

\subsubsection{The Moderating Effect of Environmental Turbulence on Entry-mode Strategy, \\ Firm-level capability, and Organisational Performance}

By description, the macro business environment is dynamic and challenging to control for organisations operating within its framework (Putri \& Salamah, 2016). Given its implication for business survival and prosperity, several empirical works have been done to substantiate its interaction on different organisational phenomena and performance relationships (BintiTaju \& Bin-Zainuddin, 2017; Turulja \& Bajgoric, 2019; Zaidi \& Othman, 2015). However, the majority of these studies did not address the above objective. The few did (Tsai \& Yang, 2013; Turulja \& Bajgoric, 2019; Zaidi \& Othman, 2015) examined whether environmental turbulence moderates the association between innovation and firm performance.

For instance, Turulja and Bajgoric (2019) examined the interactions between innovation and organisational performance under environmental turbulence for South-Eastern European firms. The study showed that environmental turbulence does not moderate the relationship between innovation and business performance. The authors found instead that ET measured as technological, market, and competitive intensity boosts innovation against moderating the association between innovation and performance. While Turulja and Bajgoric (2019) was a multi-industry study, Tsai and Yang (2013) focused on a single industry assessment to ascertain how both environmental turbulence components (market turbulence and competitive intensity) moderate the association between innovative capacity and firm performance.

Furthermore, Zaidi and Othman (2015) investigated the interactions of organisational capabilities, environmental turbulence, and NPP of manufacturing firms in Malaysia. The result showed that all the environmental turbulence components (technological, market, and competitive intensity) were significant moderators for the association between organisational capabilities and NPD financial performance. This implied that environmental turbulence components were able to explain the changes in the financial performance of NPD. It is imperative to emphasise that the organisational capabilities examined in Zaidi and Othman (2015) include exploratory and exploitative capabilities. On the contrary, further analysis showed that environmental turbulence did not moderate the relationship between organisational capabilities and new product development non-financial performance.

However, the ANOVA analyses suggested that specific environmental turbulence types moderated some of the relationships between certain types of organisational capabilities and NPD non-financial performance. On the part of Wang et al. (2015), the scholars assessed the moderating effect of market turbulence on the interactions of firm capabilities, external collaboration, and firm performance. The study revealed that market turbulence positively moderates the effects of innovation and information capabilities but not relational capability. This is because the performance-effect of innovation increased at the introduction of market turbulence. 
While these above findings are within the stated objective under review, other sub-variables such as non-equity mode, equity mode, hybrid mode strategies, customer engagement, NPD, and marketing capability are not explicitly addressed. More so, some of the sub measures in studies on organisational capabilities in studies such as Wang et al. (2015) and Zaidi and Othman (2015) are different from the measures of firm-specific capabilities under investigation this study. The significance of a one-sided analysis may not display critical assessment and accurate reflection of the variables under study/discussion. Hence, in addition to the few works cited, a theoretical approach will be employed to substantiate what interaction to expect considering environmental turbulence, entry-mode strategy, firm-level capability, and organisational performance.

Drawing from the discussions of the environmental contingency theory, an organisation's success is a function of achieving an alignment between the organisation and its environment (Meyer \& Scott, 1983). This narrative suggests that the organisation-strategy-environmental fit produces significant performance and not the strategy in isolation. Given the narratives of the ECT and the moderation perspective, this study assumes that although managers may seem to prefer a low level of environmental turbulence, this guarantees relative stability and improves business planning. Nevertheless, the development in ICT, local/global competitive rivalry, consumer expectations, regulatory policies, weak purchasing power, business opportunities/threats, and globalisation mean increasing complexity and more turbulence, which may negatively/positively affect the extent to which entry-mode strategy, firm-level capability affect the organisational performance of manufacturers of baby-care product in Lagos State, Nigeria.

\section{METHODOLOGY}

This study adopted a cross-survey research design, which enhanced data collection at a point in time to establish the effect of entry mode strategy and firm-specific capability on organisational performance (Onamusi et al., 2019).

\subsection{The Study Setting, Sample, and Data collection}

Twelve manufacturing companies in the FMCG baby-care category ranging from body-care, milk formula, baby-cereal, diaper, baby-snack, and juice were considered with 8452 management staff. Using Research advisor, 379 is an appropriate sample for that population figure. To accommodate instances of non-response, $40 \%$ of the initial sample is added to produce a sample size of 518. Consistent with prior survey studies (Asikhia et al., 2020), this study used a questionnaire with response options ranging from strongly agree to disagree strongly; to collect data from the respondents using stratified random sampling technique. After collecting the filled questionnaire, they were sorted so that a questionnaire that was not correctly filled was dropped. In all, 452 copies of the questionnaire were considered usable, representing $89.3 \%$ response rate.

\subsection{Measurement of Variable}

The variables in this study include organisational performance (dependent variable), entrymode strategies and firm-level capability (independent variables), and environmental turbulence (intervening variable). Their measurement was done in agreement with existing studies. 
Based on the articles reviewed, several scholars measured organisational performance by incorporating both financial and non-financial indicators to take advantage of the two measures' strength (Asihkia et al., 2020; Bendig et al., 2018; Vij \& Bedi, 2016).

Scholars have conceptualised and measured the entry-mode strategy as a categorical variable (Lin \& Ho, 2019; Matarazzo \& Resciniti, 2014). The categorisation includes non-equity mode, equity mode, and hybrid mode. The non-equity mode includes import and contractual arrangements such as licensing and contract manufacturing. The equity modes include investment modes such as wholly-owned subsidiaries (which can be achieved either through Greenfield or Acquisition) and joint venture. The hybrid modes involve the combination of both modes, combining importation of finished product with the wholly-owned subsidiary. Although many existing studies consider only non-equity and equity mode, this study includes the hybrid mode because of the marked peculiarity of baby-care products in Nigeria. This hybrid mode does not portray the same meaning as when companies import raw material to manufacture products in host countries. The hybrid category is in line with the work of Yasmeen and Viswanathan (2017). In line with existing studies, this study measures the entry-mode strategy as a categorical variable.

Extant literature also considered firm-level capability as internal organisation characteristics, resources, and assets that, when effectively harnessed, 'ceteris paribus' lead to competitive advantage (Andreu, Claver \& Quer, 2016; Andreu, Claver \& Quer, 2017; Contractor et al., 2016). This study investigates the following organisational capability sub-variables: customer engagement, new product development, marketing capability, and innovation capability. Based on these previous studies, customer engagement reflects the extent to which firms involve their customers in the co-creation of products. It further measures how customer insights are gathered and how customers are motivated to participate and invite other prospective customers. These elements were measured using Likert type scale by earlier scholars (Anning-Dorson, 2018; Mu et al., 2018).

New product development reflects the extent to which firms can conceive and introduce new products to the market. Previous studies measured NPD by incorporating different dimensions of NPD. The dimension includes new product introduction, time to market of the new product, the development cycle of the new product, and market potential of new products compared to the significant firm competitor. These elements were measured using a Likerttype scale by earlier scholars (Mu et al., 2017; Wei et al., 2014). Marketing capability involves multidimensional tasks. Existing studies measured marketing capability by incorporating marketing communication (Advertising), market sensing, partner linking, pricing and selling, market planning, and marketing implementation. These elements were measured using Likert type scale by earlier scholars (Mu, 2015; Mu et al., 2018).

Previous innovation capability studies considered management innovation, technical innovations (develop new products, service operations, and technology), and non-technical innovations (managerial, market, and marketing) to measure the concept. Scholars such as Foroudi, Jin, Gupta, Melewar, and Foroudi (2016) measured innovation capability using Likert type scale.

Environmental turbulent equally acts as a contextual moderator that conditions the extent to which entry-mode strategy and firm-level capability influence organisational performance. It reflects the extent of changes experienced in a firm's external environment, which can positively or negatively influence the firm's performance (Dess \& Beard, 1984; Jaworski \& 
Kohli, 1993). Both scholars employed a Likert type scale to measure environmental turbulence. In all, this study adopts similar measures for all the variables discussed above.

\subsection{Data Analysis and Mathematical Model}

The hierarchical regression analysis was adopted to establish the moderating effect of environmental turbulent on the interaction between entry mode strategy, firm-level capability, and organisational performance. The mathematical model to achieve hierarchical regression is stated below.

$\mathrm{Y}=\mathrm{f}(\mathrm{X})$

$Y=$ Outcome variable: Organisational Performance (OrgP)

$X=$ Predictor variable 1: Entry Mode Strategy (EMSG)

$\mathrm{W}=$ Predictor variable 2: Firm-level Capability (FLC)

$\mathrm{Z}=$ Moderating variables: Environmental Turbulence (ET)

To establish the joint effect of entry mode strategy and firm-level capability on organisational performance.

$$
\begin{gathered}
\mathrm{Y}=\mathrm{f}(\mathrm{X}, \mathrm{W}) \\
\mathrm{Y}=\beta \mathrm{o}+\beta 1 \mathrm{Xi}+\beta 2 \mathrm{Wi}+\mathrm{ei} \\
\operatorname{OrgP}=\beta \mathrm{o}+\beta 1 \mathrm{EMSGi}+\beta 2 \mathrm{FLC}+\mathrm{ei}---(1)
\end{gathered}
$$

To establish the moderating effect of environmental turbulence on the interaction between entry mode strategy, firm-level capability, and organisational performance.

$$
\begin{gathered}
\mathrm{Y}=\mathrm{f}\left(\mathrm{X}^{*} \mathrm{~W} * \mathrm{Z}\right) \\
\mathrm{Y}=\beta \mathrm{o}+\beta 1 \mathrm{Xi}+\beta 2 \mathrm{Wi}+\beta 3 \mathrm{Zi}+\beta 4 \mathrm{Xi}^{*} \mathrm{Wi}{ }^{*} \mathrm{Zi}+\mathrm{ei} \\
\operatorname{OrgP}=\beta \mathrm{o}+\beta 1 \mathrm{EMSGi}+\beta 2 \mathrm{FLCi}+\beta 3 \mathrm{ETi}+\beta 4 \mathrm{EMSGi}^{*} \mathrm{FLCi}^{*} \mathrm{ETi}+\mathrm{ei}--(2)
\end{gathered}
$$

\section{DATA ANALYSIS AND RESULT}

\subsection{Validity and Reliability Test}

Through the principal component analysis, the study conducted a factor analysis to establish the instrument's validity. As specified by scholars such as Hair et al. (2018), the AVE threshold of 0.5 suggests the instrument exhibits construct validity. More so, Cronbach's Alpha coefficient and Composite Reliability provide twin justification for the instrument's reliability. Below is the tabulated result of the validity and reliability statistic.

Table 1 presents hierarchical multiple regression results for the moderating effect of environmental turbulence on the interactions between entry-mode strategy, firm-level capability, and organisational performance. First, the effect of entry mode strategy and firmlevel capability on organisational performance was examined. Second, the effect of entry mode strategy, firm-level capability, and environmental turbulence on organisational performance were examined. Lastly, the moderating effect of environmental turbulence on the interaction between entry mode strategy, firm-level capability, and organisational performance was examined and discussed accordingly. 
In the first model, it was discovered that entry mode strategy and firm-level capability accounted for $69.5 \%$ of the variance recorded in organisational performance $(\mathrm{R}=0.835$, Adj. $\left.R^{2}=0.695, F(3,448)=344.128, \mathrm{p}=0.000\right)$. In the second model, entry mode strategy, Firmlevel capability and environmental turbulence explained $73.8 \%$ variation in organisational performance (Adj. R2 = 0.738, 314.798(4,447), p=.000). In the third model, when the interaction term of entry mode strategy, firm-level capability, and environmental turbulence was incorporated into the regression analysis, organisational performance increased by $1.7 \%$ $((\Delta R 2=0.017, \Delta F=31.366, \mathrm{P}=0.000)$ because $\mathrm{R} 2$ increased from 0.695 (in model one) to 0.752 (in model three). This result shows that environmental turbulence has a significant moderating effect on the interaction between entry mode strategy, firm-level capability, and organisational performance.

Table 1. Validity and Reliability Statistics

\begin{tabular}{|c|c|c|c|c|c|}
\hline Variables & Items & Loadings & $\mathbf{C A}$ & $\mathbf{C R}$ & AVE \\
\hline \multicolumn{6}{|c|}{ Firm-level capability: } \\
\hline & Manage corporate image & 0.60 & 0.78 & 0.86 & 0.60 \\
\hline \multirow{6}{*}{$\begin{array}{l}\text { Marketing } \\
\text { Capability }\end{array}$} & Support Sales Reps & 0.83 & & & \\
\hline & Segment market & 0.83 & & & \\
\hline & Allocate market resources effectively & 0.84 & & & \\
\hline & Alert to market dynamics & 0.72 & & & \\
\hline & Monitor Competitors' price changes & 0.72 & & & \\
\hline & Anticipate market trends & 0.81 & & & \\
\hline \multirow{4}{*}{$\begin{array}{l}\text { New product } \\
\text { Development }\end{array}$} & Improve production process & 0.57 & 0.82 & 0.84 & 0.58 \\
\hline & Highly innovative product & 0.86 & & & \\
\hline & First to introduce product & 0.84 & & & \\
\hline & Cost reduction & 0.74 & & & \\
\hline \multirow{4}{*}{$\begin{array}{l}\text { Customer } \\
\text { Engagement }\end{array}$} & Co-create with customers & 0.85 & 0.77 & 0.82 & 0.54 \\
\hline & Interact with customers & 0.80 & & & \\
\hline & Attend to customer needs & 0.70 & & & \\
\hline & Immerse in customer reality & 0.54 & & & \\
\hline \multirow{4}{*}{$\begin{array}{l}\text { Innovation } \\
\text { Capability }\end{array}$} & Support production unit & 0.89 & 0.82 & 0.86 & 0.62 \\
\hline & Innovate manufacturing processes & 0.88 & & & \\
\hline & Quality management system & 0.73 & & & \\
\hline & Innovate business process & 0.61 & & & \\
\hline \multirow{4}{*}{$\begin{array}{l}\text { Environmental } \\
\text { Turbulence }\end{array}$} & Favourable policy & 0.85 & 0.80 & 0.86 & 0.60 \\
\hline & Environmental challenges & 0.80 & & & \\
\hline & Economic munificence & 0.75 & & & \\
\hline & Technological dynamism & 0.69 & & & \\
\hline \multirow{6}{*}{$\begin{array}{l}\text { Organisational } \\
\text { Performance }\end{array}$} & Acquire New Market & 0.88 & 0.89 & 0.83 & 0.71 \\
\hline & Customer satisfaction & 0.83 & & & \\
\hline & Gross profit margin & 0.89 & & & \\
\hline & Achieving financial target & 0.71 & & & \\
\hline & Net profit margin & 0.83 & & & \\
\hline & Sales growth & 0.88 & & & \\
\hline
\end{tabular}

Source: Researcher's Results (2020) 
Table 2. Summary of hierarchical regression analysis for the moderating effect of environmental turbulence on the relationship between entry-mode strategy, firm-level capability, and organisational performance

\begin{tabular}{|c|c|c|c|c|c|c|c|c|c|}
\hline $\begin{array}{c}\text { Model }^{1,2,3} \\
{\text { (Constant })^{1}}^{1}\end{array}$ & $\begin{array}{r}\text { Beta } \\
1.758\end{array}$ & $\begin{array}{c}\mathrm{t} \\
17.760\end{array}$ & $\begin{array}{l}\text { Sig. } \\
.000\end{array}$ & $\begin{array}{r}\mathrm{R} \\
.835\end{array}$ & $\begin{array}{r}\mathrm{R}^{2} \\
.697\end{array}$ & $\begin{array}{l}\text { Adj. } \mathrm{R}^{2} \\
.695\end{array}$ & $\begin{array}{c}\Delta \mathrm{R}^{2} \\
.697\end{array}$ & $\begin{array}{c}\Delta \mathrm{F} \\
344.128\end{array}$ & $\begin{array}{l}\text { Sig. F } \\
\text { Change } \\
.000\end{array}$ \\
\hline $\begin{array}{l}\text { Non-equity } \\
\text { mode }\end{array}$ & -.161 & -5.262 & .000 & & & & & & \\
\hline Equity mode & .364 & 12.870 & .000 & & & & & & \\
\hline $\begin{array}{l}\text { Firm-level } \\
\text { capability }\end{array}$ & .872 & 30.121 & .000 & & & & & & \\
\hline \multicolumn{10}{|c|}{$\begin{array}{l}\text { F \& Anova Sig: } 344.128(3,448) \\
p=.000\end{array}$} \\
\hline$(\text { Constant })^{2}$ & 1.349 & 12.911 & .000 & $.859^{\mathrm{b}}$ & .738 & .736 & .041 & 69.335 & .000 \\
\hline $\begin{array}{l}\text { Non-equity } \\
\text { mode }\end{array}$ & -.127 & -4.419 & .000 & & & & & & \\
\hline Equity mode & .259 & 8.874 & .000 & & & & & & \\
\hline $\begin{array}{l}\text { Firm-level } \\
\text { capability }\end{array}$ & .796 & 28.013 & .000 & & & & & & \\
\hline $\begin{array}{l}\text { Environmental } \\
\text { Turbulence }\end{array}$ & .235 & 8.327 & .000 & & & & & & \\
\hline $\begin{array}{l}\mathrm{F} \& \text { Anova } \\
\mathrm{p}=.000\end{array}$ & \multicolumn{9}{|c|}{ Sig: $\quad 314.798(4,447)$} \\
\hline$(\text { Constant })^{3}$ & .741 & 5.000 & .000 & $.869^{\mathrm{c}}$ & .755 & .752 & .017 & 31.366 & .000 \\
\hline $\begin{array}{l}\text { Non-equity } \\
\text { mode }\end{array}$ & .297 & 3.681 & .000 & & & & & & \\
\hline Equity mode & .785 & 8.007 & .000 & & & & & & \\
\hline $\begin{array}{l}\text { Firm-level } \\
\text { capability }\end{array}$ & .877 & 28.229 & .000 & & & & & & \\
\hline $\begin{array}{l}\text { Environmental } \\
\text { Turbulence }\end{array}$ & .355 & 10.229 & .000 & & & & & & \\
\hline EMS*FLC*ET & -.608 & -5.601 & .000 & & & & & & \\
\hline
\end{tabular}

a. Predictors: (Constant), Entry-Mode Strategy, Firm-level capability *Hybrid strategy is the reference category

b. Predictors: (Constant), Entry-Mode Strategy, Firm-level capability, Environmental turbulence

c. Predictors: (Constant), Entry-Mode Strategy, Firm-level capability, Environmental turbulence, EMS*FLC*ET denote Entry-Mode Strategy*Firm-level capability* Environmental turbulence

d. Dependent Variable: Organisational Performance

Source: Researcher's Field Survey Results (2020)

\section{DISCUSSIONS, CONCLUSIONS AND RECOMMENDATIONS}

Conceptually, environmental turbulence presents uncertain consequences for business firms. While its ripple effect may offer agile firms the opportunity and potentials for growth, however, the risks and challenges presented by the unpredictability of a turbulent environment are of concern to every firm because managers are unable to make a reasonable long-time plan and make predictions that can aid performance (Dess \& Beard, 1984). The narrative suggests that environmental turbulence could have positive or negative effects for firms operating within its scope. Onamusi et al. (2019) corroborate Dess and Beard (1984) to suggest that despite the challenges within a turbulent environment that can negatively affect firms operating within its framework, there are munificent factors that present growth potential for agile firms. 
Empirically, this study reveals that environmental turbulence moderates the relationship between entry-mode strategy, firm-level capability, and organisational performance. This finding corroborated Dess and Beard (1984) and Jaworski and Kohli (1993), who posited that environmental turbulence could influence organisational performance. The contingency perspective equally suggested that the relationship between a predictor and an outcome variable can either experience an increase or decrease effect with introducing a third variable. The study conducted by Rasheed (2005) on the performance effect of foreign market entrymode among 123 mid-sized US manufacturing firms presented additional support for the findings of this study result. The study revealed that the alignment between the foreign market entry-mode and the host country's environmental factors increased firm performance. Although Luo (2001) found support for the moderating effects of the environment on the strategy- performance relationship for small businesses in China, the application of this contingent performance model to foreign market entry is not well established in entry-mode studies.

Concerning firm-level capability studies, Tsai and Yang (2013) focused on single industry assessment to ascertain how environmental turbulence components (market turbulence and competitive intensity) moderate the association between firm-level capability (innovative capability) and firm performance. The findings emphasised that environmental turbulence significantly moderated changes and strength of the performance effect of firm performance. Similar support was found in Zaidi and Othman (2015). The scholars investigated the interactions of organisational capabilities, environmental turbulence, and NPP of manufacturing firms in Malaysia. The result showed that all the environmental turbulence components (technological, market, and competitive intensity) were significant moderators for the association between organisational capabilities and NPD financial performance.

This implied that environmental turbulence components were able to explain the changes in the financial performance of NPD. It is imperative to emphasise that the organisational capabilities examined in Zaidi and Othman (2015) include exploratory and exploitative capabilities. On the part of Wang et al. (2015), the scholars revealed that market turbulence positively moderates firm-level capability (innovation) because the performance-effect of innovation increased at the introduction of environmental market turbulence. In contrast, when Turulja and Bajgoric (2019) examined the interactions between firm-level capability (innovation) and organisational performance under environmental turbulence for SouthEastern European firms. The study showed that environmental turbulence does not moderate the relationship between firm-level capability (innovation capability) and business performance.

Drawing from the environmental contingency theory (ECT), the organisation's success is a function of the fit between the organisation and its business environment (Meyer \& Scott, 1983). Specifically, ECT stated that it is the fit between a strategy and the business environment, rather than mere strategy determines business performance (Donaldson, 2001). This is corroborated by Okafor (2017). According to the scholar, a firm's environment, to a large extent, affects its operations and success. In concomitant with the ECT narratives, the moderation perspective as earlier discussed, and the findings of this study, it can be concluded that environmental turbulence moderates the interaction of entry-mode strategy, firm-level capability, and organisational performance of selected manufacturers of baby-care products in Lagos State, Nigeria. 
Given environmental turbulence potentially carries both threats and opportunities for companies; hence, the management of FMCG companies understudy should ensure that the choice of an entry-mode strategy must be environment-appropriate. More so, since environmental turbulence moderates the interaction between entry-mode strategies, firmspecific capabilities, and organisational performance, hence, management needs to keep abreast of issues happening in the external environment and proactively position their organisation to take advantage of the opportunities presented by the environment while reducing exposure to negative consequences.

\section{ACKNOWLEDGEMENTS}

We like to acknowledge the department of business administration Lead City University, Ibadan, and the department of business administration and marketing Babcock University Ilishan-Remo for creating the platform for developing research capacity. We appreciate Prof. Asikhia Olalekan of the department of Business Administration and Marketing Babcock University, for taking the time to review this paper.

\section{REFERENCES}

Andreu, R., Claver, E., \& Quer, D. (2016). Firm-specific factors and entry-mode choice. Tourism Economics, 23(4), 756-767.

Andreu, R., Claver, E., \& Quer, D. (2017). Foreign market entry-mode choice of hotel companies: Determining factors. International Journal of Hospitality Management, 62(9), 111-119.

Anning-Dorson, T. (2018). Customer involvement capability and service firm performance: The mediating role of innovation. Journal of Business Research, 86(4), 269-280.

Anning-Dorson, T. (2018). Innovation and competitive advantage creation. International Marketing Review, 35(4), 580-600.

Arasa, R. \& Gideon, R.N. (2015). The influence of international market entry strategies on firm performance: A study of the manufacturing multinationals in Kenya. International Journal of Economics, Commerce and Management, 3(9), 364-386

Asikhia, O. U., \& Makinde, G. O., \& Onamusi, A. B. (2020). Marketing capability and firm performance: Mediating role of new product development and management innovation. The International Journal of Business \& Management, 8(2), 69-77.

Bendig, D., Enke, S., Thieme, N., \& Brettel, M. (2018). Performance implications of crossfunctional coopetition in new product development: The mediating role of organisational learning. Industrial Marketing Management, 18(4), 66-80.

Binti-Taju-Rahim, F., \& Bin-Zainuddin, Y. (2017). Moderating effect of environmental turbulence on firm's technological innovation capabilities (TIC) and business performance in the automotive industry in Malaysia: A conceptual framework. MATEC Web of Conferences, 90, 01009.

Brouthers, K. D., \& Hennart, J. F., (2007). Boundaries of the firm: Insights from international entry-mode research. Journal of Management, 33(3), 395-425.

Chukwuemeka, O.W., \& Onuoha, B.C. (2018). Dynamic capabilities and competitive advantage of fast foods restaurants. International Journal of Management Science and Business Administration, 4(3), 7-14.

Contractor, F., Yang, Y., \& Gaur, A.S. (2016). Firm-specific intangible assets and subsidiary profitability: The moderating role of distance, ownership strategy and subsidiary experience. Journal of World Business, 51(6), 950-964. 
Dess, G.G., \& Beard, D.W. (1984). Dimensions of organisational task environments. Administrative Science Quarterly, 29(1), 52-63.

Donaldson, L. (2001). The contingency theory of organisations. London; Sage.

Dunning, J.H. (2000). The eclectic paradigm as an envelope for economic and business theories of MNE activity. International Business Review, 9(2), 163-190.

Euromonitor International. (2017). Baby food in Nigeria. Retrieved from Euromonitor International Passport website: http://www.Euromonitor International.com

Euromonitor International. (2018). Baby and child-specific product in Nigeria. Retrieved from Euromonitor International Passport website: http://www.Euromonitor International.com

Euromonitor International. (2019). Baby and child-specific product in Nigeria. Retrieved from Euromonitor International Passport website: http://www.Euromonitor International.com

Foroudi, P., Jin, Z., Gupta, S., Melewar, T., \& Foroudi, M.M. (2016). Influence of innovation capability and customer experience on reputation and loyalty. Journal of Business Research, 69(11), 4882-4889.

Hair, J. F., Black, W. C., Babin, B. J., \& Anderson, R. E. (2018). Multivariate data analysis, 8th ed., Andover, Hampshire: Cengage Learning, EMEA.

Hollender, L., Zapkau, F. B., \& Schwens, C. (2017). SME foreign market entry-mode choice and foreign venture performance: The moderating effect of international experience and product adaptation. International Business Review, 26(2), 250-263.

Jaworski, B.J., \& Kohli, A.K. (1993). Market orientation: Antecedents and consequences. Journal of Marketing, 57(3), 53-64.

Kaur, V., \& Mehta, V. (2017). Dynamic capabilities for competitive advantage: A comparative study of IT multinationals in India. Paradigm, 21(1) 31-51.

Kimura, Y., \& Pugel, T.A. (1995). Keiretsu and Japanese direct investment in US manufacturing. Japan and the World Economy, 7(4), 481-503.

Lee, P., Wu, M., Kuo, C., \& Li, C.J. (2016). How to deploy multiunit organisations' dynamic capabilities? Management Decision, 54(4), 965-980.

Lekhanya, L. M., Olajumoke, N. G., \& Nirmala, D. (2017). Exploring fast moving consumer goods (FMCG) small, medium and micro enterprises manufacturers' need for innovation to achieve growth. Environmental Economics, 8(2), 8-16.

Lin, F., \& Ho, C. (2019). The knowledge of entry-mode decision for small and medium enterprises. Journal of Innovation \& Knowledge, 4(1), 32-37.

Luo, Y. (2001). Determinants of entry in an emerging economy: A multilevel approach. Journal of Management Studies, 38(3), 443-472.

Matarazzo, M., \& Resciniti, R. (2014). New trends in foreign market entry-mode choices: The case of Italian mid-sized companies. Journal of International Business and Economics, 2(4), 57-70.

Meyer, J. W., \& Scott, R. W. (1983). Organisational environments: Ritual and rationality. Beverly Hills, CA: Sage.

Mu, J., Bao, Y., Sekhon, T., Qi, J., \& Love, E. (2018). Outside-in marketing capability and firm performance. Industrial Marketing Management, 75(6), 37-54.

Mu, J., Thomas, E., Peng, G., \& Di Benedetto, A. (2017). Strategic orientation and new product development performance: The role of networking capability and networking ability. Industrial Marketing Management, 64(8), 187-201.

$\mathrm{Mu}$, J. (2015). Marketing capability, organisational adaptation and new product development performance. Industrial Marketing Management, 49(7), 151-166.

NPC. (2018). Population statistics in Nigeria. Retrieved from NPC website: http://www.npc.org.ng 
Nisar, S., Boateng, A., \& Wu, J. (2018). The entry-mode strategy and performance of SMEs: Evidence from Norway. Research in International Business and Finance, 45(6), 323333.

Okafor, G. (2017). The determinants of firm performance and bribery: Evidence from manufacturing firms in Nigeria. International Economic Journal, 31(4), 647-669.

Onamusi, A. B., Asikhia, O. U., \& Makinde, O. G. (2019). Environmental munificence and service firm performance: The moderating role of management innovation capability. Business Management Dynamics, 9(6), 13-25.

Putri, K, D., \& Salamah, U. (2016). Environmental contingency theory: Organisation and the environment. International Business Review, 69(2), 277-284.

Rasheed, H. S. (2005). Foreign entry-mode and performance: The moderating effects of environment. Journal of Small Business Management, 43(1), 41-54.

Siripaisalpipat, P., \& Hoshino, Y. (2000). Firm-specific advantages, entry-modes, and performance of Japanese FDI in Thailand. Japan and the World Economy, 12(1), 33-48.

Sylva, W., Ofoegbu, C. W., \& Akpan, E. E. (2016). The impact of knowledge management on product innovation of manufacturing firms in Nigeria. Information and Knowledge Management, 6(6), 78-87.

Teece, D. J. (2014a). A dynamic capabilities-based entrepreneurial theory of the multinational enterprise. Journal of International Business Studies, 45(1), 8-37.

Tsai, K., \& Yang, S. (2013). Firm innovativeness and business performance: The joint moderating effects of market turbulence and competition. Industrial Marketing Management, 42(8), 1279-1294.

Turulja, L., \& Bajgoric, N. (2019). Innovation, firms' performance and environmental turbulence: Is there a moderator or mediator? European Journal of Innovation Management, 22(1), 213-232.

Ukpabio, M. G., Oyebisi, T. O., \& Siyanbola, W.O. (2017). Technological innovation and performance of manufacturing firms in Nigeria. International Journal of Innovative Research and Advanced Studies, 4(11), 201-217.

Vij, S., \& Bedi, H. S. (2016). Are subjective business performance measures justified? International Journal of Productivity and Performance Management, 65(5), 603-621.

Wang, G., Dou, W., Zhu, W., \& Zhou, N. (2015). The effects of firm capabilities on external collaboration and performance: The moderating role of market turbulence. Journal of Business Research, 68(9), 1928-1936.

Wei, Z., Yi, Y., \& Guo, H. (2014). Organisational learning ambidexterity, strategic flexibility, and new product development. Journal of Product Innovation Management, 31(4), 832-847.

Westat Country Research. (2018). In-country assessments of baby food companies' compliance with the international code of marketing of breast-milk substitutes. Retrieved from Westat Country Research website: http://www.westatcountryresearch.com

Yasmeen, K., \& Viswanathan, K. (2017). Influence of country factors on entry-mode through knowledge and transactional cost economics: Market entry evidence from construction firms. International Journal of Economics and Financial Issues, 7(3), 581-585.

Zaidi, M. F., \& Othman, S. N. (2015). Organisational capabilities, environmental turbulence, and NPD performance: A study on Malaysian manufacturing firms. Procedia - Social and Behavioural Sciences, 172(9), 286-293.

Zhang, M., \& Hartley, J. L. (2018). Guanxi, IT systems, and innovation capability: The moderating role of proactiveness. Journal of Business Research, 90(5), 75-86. 